\title{
POVERTY, DEVELOPMENT AND DISABILITY
}

\section{N Gathiram}

\section{INTRODUCTION}

Hendriks (1999:111) highlights the point that all studies during the past decade indicate, namely that person's with disabilities and their families are disproportionately represented amongst the poorest of poor. With the change of perception of persons with disabilities, it is now realised that environmental factors and the context in which such persons live are crucial in the success of their becoming productive members of society. As a result of this understanding, the socio-economic empowerment of persons with disabilities within a developmental framework is being advocated. The author will highlight the need for synergy between mainstream development and those developments specifically for persons with disabilities, given the South African context. In South Africa the majority of the population lives in poverty and in underdeveloped communities with few resources and opportunities. It is argued that it would be difficult to meet the needs of the disabled in these circumstances. In such situations most disability issues are important to all development: equality, empowerment, human rights, poverty and marginalisation (Lee cited in Yeo, 2001:8). In the light of this, the author stresses the need for, and the benefit of, integrating disability issues into all development programmes at community level. The integration of disability issues into all development programmes is a cost-effective approach in dealing with poverty and disability in resource-poor settings. Challenges in implementing this approach will be discussed.

The paper hopes to stimulate thinking and debate around the issue of poverty and disability at a crucial time. There is concern that if the development target set by the Organisation of Economic Cooperation and Development (OECD) - of halving the number of people living in extreme poverty by the year 2015 - is to be achieved, the high levels of poverty amongst persons with disability has to be addressed (Yeo, 2001:5). The disability movement in Africa has officially declared 2000-2009 the African Decade of Disabled Persons, with the long-term objective being poverty alleviation amongst citizens with disabilities and their families. The Minister of Social Development in South Africa identified the redesigning of services to people with disabilities to promote their human rights and economic development as one of the priorities over the subsequent five years (since 2000). These policy changes pose a challenge to those involved in implementation. This article will be of value to policy makers, developmental experts, rehabilitators, human rights activists and people with disabilities themselves. Social workers are prominent in all of these roles.

\section{DISABILITY AND POVERTY}

An understanding of the relationship of poverty and disability is important as it guides policy formulation and intervention strategies. Metts (cited in Yeo, 2001:8) estimates in a World Report that "half a billion disabled people are amongst the poorest of the poor". Elwan (1999:iv) states that the disabled comprise $15-20 \%$ of the poorest people in developing countries. He states further that they are more likely to have incomes below poverty level, and less likely to have savings and other assets than the non-disabled population (Elwan, 1999:iv). Despite the lack of research and discrepancies in the estimation of the numbers of people with disabilities in South Africa, at least $16 \%$ of South Africans are themselves disabled or live in a household with a person who is disabled (1995 October Household Survey, cited in CICSS, 2002). 
Disability and poverty are mutually reinforcing. People with disabilities are caught in a vicious cycle, unable to escape the poverty trap. Poverty is a cause of disability. The poor living conditions of those living in poverty often predispose them to illness, injury and impairments. It is generally believed that communicable diseases, malnutrition, low-quality prenatal care, accidents or violence are the major causes of disability in developing countries (Mendis, 1994:533).

Disability also causes poverty (Coleridge, 1993; Elwan, 1999; Moodley, 1997). The reduced capability of the physical disability limits participation in employment and the economy (Turmusani, 2003:26). Disability often results in the loss of earning of the person and of caregivers. Additional costs of care, the need for assistive devices and medical costs could result in poverty of the individual and the family (Turmusani, 2003:30). Yeo (2001:11), a proponent of the social model of disability, is of the opinion that the basic cause of poverty, particularly with disability, is exclusion. People with disabilities are at risk of being excluded from economic, educational, social and political life as a result of the disability and discrimination in society. Thus poverty extends beyond merely not having finances into social impoverishment (Skidmore, 1994). There can be no ordinary life and control over choice or exercise of responsibility in conditions of poverty. Therefore poverty has many socio-economic repercussions on the disabled, their families, the communities in which they live and the economy of the country.

\section{GLOBAL AND NATIONAL TRENDS WITH REGARDS TO APPROACHES TO DISABILITY}

During the last three decades different approaches to disability have emerged which have guided social policy and practice in various countries. Previously the individualistic medical model of disability was dominant. It defines disability as a medical defect, which implies a human need to be cured or cared for (Turmusani, 2003:6). However the perception of people with disabilities has changed with the emergence of the social model. Society's disabling barriers and power relations, rather than only the individual's impairment, are now seen as affecting the quality of life. Exclusion from society is central to poverty causation, denying the disabled equal opportunities to improve their living conditions and life chances. The disability that may result from a given impairment is not a direct function of anatomic loss or degree of functional limitation, but is influenced by self-concept, social support, definition of illness and many other variables (Locker, 1983:2). The unified assessment tool of an individual's functioning capacity of the World Health Organisation now recognises environment factors and the context in which an individual lives as important components. It is now called the International Classification of functioning, disability and health (ICF). This reflects a move away from a "consequence of disease" classification to a "components of health" classification (Child Health Policy Institute, 2001:5).

This change in understanding of disability and poverty has led to a developmental approach being adopted to deal with the problem (Coleridge, 1993; Moodley, 1997). The developmental approach is consistent with the socio-political model of disability (Turmusani, 2003:7). Within a development approach, a community-based rehabilitation model has been adopted as a worldwide solution to the social integration of persons with disabilities into society (Chermak, 1990:123).

South Africa's policies are based on the principles of the United Nations Standard Rules for the Equalization of Opportunities for People with Disabilities and The World Programme of Action concerning Disabled Person's (Ministry in the Office of the President, 1997). An Integrated National Disability Strategy (INDS) was adopted in South Africa in 1997. It recognises that disability is not a health or welfare issue but a developmental concern. This implies a move away from the passive income maintenance of grants to the integration of social security, community development and social development (Ministry for Welfare and Population Development, 
1997:47). The INDS states that there must be an integration of disability issues in all government development strategies, planning and programmes (Ministry in the Office of the President, 1997:19). To facilitate this integration an Office on the Status of Disabled Person's has been established in the President's Office. A primary health care approach within a district health system has been adopted. Within this framework services are to be based on a community-based rehabilitation model. The implementation of these policies poses a challenge to practitioners, given the conditions in communities and the limited resources that are available to extend services to those who were previously excluded from the formal system.

\section{WHY INTEGRATED DEVELOPMENT?}

Dealing with poverty and disability in South Africa is complex, given a society of gross inequality and where the majority of the population lives in poverty and in underdeveloped resource-poor settings. According to Mhone (2004:8), the sad truth is that an estimated 18 million persons, out of a population of roughly 42 million, have been found to live in absolute poverty. The author supports the philosophy of the community-based rehabilitation model that it is only when issues related to disability are considered to be part of overall community development that equalisation of opportunities and fulfilment of rights are possible (Mendis, 1994:537). She will argue the importance of the proper implementation of South African disability policies in that poverty and disability, given the South African context, cannot be dealt with in isolation and have to be in synergy with mainstream development at community level.

Firstly, until poverty in the general population has been addressed, the quality of life of people with disabilities will be low. In situations of dire poverty it is not surprising that persons with disability have the lowest priority for any limited resources. Ashton (cited in Yeo, 2001:9) is of the opinion that scarce resources have to be used for the survival of the fittest in poverty situations. She cites the example of the lack of investment in disabled children as a desperate but rational decision in such situations. The care of persons with disabilities is compromised in poor households. Lund (1997:370) in her research found that, although the disability grant is claimed by the individual disabled person, it is used for general household expenses in the three-generational household in which many poor black people live.

Lack of infrastructure, services and transport was reported by persons with disability as a significant factor contributing to making their life difficult (CASE, 1999:13). In South Africa the majority of the population (75\%) lives in rural areas, with $40 \%$ poverty and where health and welfare are least developed (GCIS, 2004:341). In these poor communities there is a lack of basic infrastructure and limited access to social, health and public services for the general population. Until development takes place in these resource-poor communities, they will not be able to cater and support the additional practical needs of persons with disabilities to enable them to participate in the economy. In addition co-ordination of sectors and services is needed within society in order to support the special needs of the disabled (Mendis, 1994:537).

The labour market represents a key arena for socio-economic empowerment (Mhone, 2004:4). Ninety-nine percent (99\%) of people with disabilities are unemployed in South Africa (Schriner, 2001). This is not surprising, when there is an unemployment rate of $26.2 \%$ in the general population as reported by Statistics South Africa. Employment opportunities need to be created for able-bodied people, persons with disabilities and their caregivers. According to Gathiram and Hemson (2002:215), local economic development is necessary in poor communities if people are to be given the opportunity for employment. Once again the quality of life of the disabled is dependent on the level and pace of development taking place in the wider community. Therefore intervention strategies to overcome poverty cannot focus on disability in isolation. 
Community development has been adopted as an appropriate strategy by South African policies to overcome poverty in the general population and with persons with disabilities (Ministry for Welfare and Population Development, 1997; Ministry in the Office of the President, 1997). Community development extends beyond economic empowerment to include social empowerment, which equips people with skills necessary to deal with social exclusion and to assert their rights. Community development is integral to community-based rehabilitation, which recognises that disability issues cannot be isolated from overall community development, as discussed earlier in the paper. Yeo (2000:18) argues that in most countries government services for disabled people are still small-scale rehabilitation projects separated from the rest of the community. She adds that these isolated projects are extremely high cost, meet the needs of only a few disabled people and do not address the underlying causes of chronic poverty: exclusion and lack of equal rights (Yeo, 2000:18). Community-based rehabilitation allows for the central role of disabled people in planning, development, implementation and monitoring of rehabilitation services (Mendis, 1994:537). Mendis (1994:537) further elaborates that community development is empowering and proposes that self-help groups have to address the causes of their oppression, discrimination and poverty. Strategies are designed to empower, educate and provide employment opportunities for people with disabilities. Thus community development skills and techniques for organising groups, enhancing community support and networks would be necessary for the whole population in poor, impoverished South African communities. In fact, having an empowered and active community would benefit persons with disability. In deprived communities where the additional practical needs of persons with physical disabilities are not met, it would be difficult for them to campaign, exert influence and to reduce their own poverty. In such situations it is important for members in communities in the interim to advocate for the rights of persons with disabilities in order to create opportunities for their participation. Advocacy would also be necessary for severely disabled people who do not have the capacity to be involved in community development efforts. Further when disability issues are mainstreamed, discrimination maybe overcome as people with disabilities become visible as productive members of society.

Finally, Turmasani, (2003:30) argues that poverty alleviation and prevention are one of the most important strategies to deal with disability and poverty. Parental education (especially maternal), awareness and access to information, dietary and food preparation habits, and the general level and coverage of primary health care have been found to have a greater (preventative) effect than any specific interventions (Khan \& Durkin cited in Elwan, 1999:22). Therefore, in South Africa given the high rates of poverty in communities, disability prevention interventions must be included in all developmental programmes as the poor are vulnerable to disability.

Internationally, the trend is that disability issues are being increasingly included in the work of mainstream agencies (Yeo, 2001:18). However, it is important to point out that there would still be a need for disability-specific programmes to deal with the special needs and rights of persons with disabilities, which is beyond the scope of this paper.

\section{CHALLENGES}

Disability as a development issue has implications for practice. There needs to be a change in professional values and practice. Practice should be premised on empowerment, equity, human rights and independence of the poor. Training institutions need to include disability in the curriculum of all development practitioners. Agencies would need to become inclusive and cater for the special needs of people with disability. The physical structures and built environment of all organisations should be accessible to persons with physical disabilities. All practitioners would need to be competent in alternative forms of communication. Empirical research needs to be 
encouraged in the field of disability, poverty and development and best practice models developed and shared with all stakeholders.

\section{CONCLUSION}

Poverty and disability are a growing concern nationally and internationally because of the impact they have on the individual, family, community and the economy. If disability is to be regarded as a development issue, the whole community has to be involved rather than their being dealt with as an isolated rehabilitation issue. The quality of life of the disabled is dependent on environmental factors. Therefore, in poor communities there is a need for synergy between mainstream development and those developments that are disability specific. To a large extent common strategies and interventions are required to overcome poverty in the general population and amongst persons with disabilities. Services should be co-ordinated and integrated in order to maximise limited resources.

\section{REFERENCES}

CASE - COMMUNITY AGENCY FOR SOCIAL ENQUIRY 1999. "We also count" The extent of moderate to severe reported disabilities and the nature of the disability experience in South Africa. Summary Report. CASE Disability survey for the Department of Health.

CHERMAK, G.D. 1990. A global perspective on disability: A review of efforts to increase access and advance social integration for disabled persons. International Disability Studies, 12(3):123127.

CHILD HEALTH POLICY UNIT. 2001. Summary of literature: Disability and chronic illness prevalence in children in South Africa. Rondebosch.

COLERIDGE, P. 1993. Disability, liberation and development. UK: Oxfam.

ELWAN, A. 1999. Poverty and disability: A survey of the literature. Social Protection Discussion Paper Series. Social Protection Unit. Human Development Network. The World Bank. Washington DC: World Bank.

GATHIRAM, N. \& HEMSON, D. 2002. Transformation of welfare? Race, class, and gender in the management of welfare agencies in South Africa. Community Development Journal, 37(3):209-219.

GCIS - GOVERNMENT COMMUNICATION AND INFORMATION SYSTEM, 2004. South African Yearbook 2003/04. Pretoria: Government Printers.

HENDRIKS, A. 1999. Disabled Persons and Their Right to Equal Treatment: Allowing Differentiation While Ending Discrimination. In: MANN, J., GRUSKIN, S. GRODIN, M. \& ANNAS, G. Health and human rights. New York: Routedge: 113-125.

LOCKER, D. 1983. Disability and disadvantage: The consequence of chronic illness. London: Travistock Publications.

LUND, F. 1997. Social security for disabled people in South Africa: Challenges facing the new society. In: DE JONG, P. \& MARMOR, T. (eds) Social policy and the labour market (vol 2). Hampshire: Ashgate Publishing Company: 363-377.

MENDIS, P. 1994. Disability prevention and rehabilitation. In: LANKINEN, K., BERGSTROM, S. et al. (eds) Health and disease in developing countries. London: Macmillan Press: 532-542. 
MHONE, G.C.Z. 2004. The socio-economic context and aspects of social security policy in South Africa. In: OLIVIER, M. et al. (eds) Introduction to social security. Durban: Lexis/Nexis Butterworths.

MINISTRY FOR WELFARE AND POPULATION DEVELOPMENT, SOUTH AFRICA. 1997. White Paper for Social Welfare. Pretoria: Government Printers.

MINISTRY IN THE OFFICE OF THE PRESIDENT, 1997. The Integrated National Disability White Paper. Pretoria: Government Printers.

MOODLEY, G. 1997. Disability, employment, and development: The economic integration of physically disabled adults into the open labour market, With special reference to the analysis of trends in the greater Durban Metropolitan Area (GDMA). Durban: University of Natal. (Unpublished MSc Thesis)

REPORT OF THE COMMITTEE OF INQUIRY INTO THE COMPREHENSIVE SYSTEM OF SOCIAL SECURITY FOR SOUTH AFRICA (CICSS), 2002. Transforming the Present Protecting the Future. Available: http://www.welfare.gov.za [Accessed 15/7/2004].

SCHRINER, K. 2001. A bimonthly web-zone of international disability news and views. Nos.11. Nov-Dec 2001. Available: http://www.disabilityworld.org/11-12_01/il/southafrica2.shtml [accessed: 15/3/2005].

SKIDMORE, D. 1994. The ideology of community care. London: Chapman Hall.

STATISTICS SOUTH AFRICA. Stats Online "the digital face of Stats SA". Available: http://www.statssa.gov.za/ [accessed 7/4/2005].

TURMUSANI, M. 2003. Disabled people and economic needs in the developing world. A political perspective from Jordan. Hampshire: Ashgate Publishing Limited.

YEO, R. 2001. Chronic poverty and disability. Chronic Poverty Research Centre. Background Paper number 4. Somerset: Action on Disability and Development.

Dr Neeta Gathiram, Senior Lecturer in the School of Social Work and Community Development, University of KwaZulu-Natal, South Africa. 